\title{
First Report on Quinone Outside Inhibitor Resistance of Alternaria alternata Causing Alternaria Brown Spot in Tangerines in São Paulo, Brazil
}

\author{
Gabriel M. Chitolina, ${ }^{1,+}$ Geraldo J. Silva-Junior, ${ }^{2}$ Eduardo Feichtenberger, ${ }^{3}$ Rosana G. Pereira, ${ }^{2}$ and Lilian Amorim ${ }^{1}$ \\ ${ }^{1}$ Escola Superior de Agricultura "Luiz de Queiroz", Universidade de São Paulo, 13418-900, Piracicaba, SP, Brazil \\ ${ }^{2}$ Fundo de Defesa da Citricultura, 14807-040, Araraquara, SP, Brazil \\ ${ }^{3}$ Instituto Biológico, 18013-440, Sorocaba, SP, Brazil
}

Accepted for publication 17 March 2019.

Keywords: fungicide resistance, Qol, mandarins, Citrus spp., chemical control

Alternaria brown spot, caused by Alternaria alternata (Fr.:Fr.) Keissler, is the most important disease of tangerines (Citrus reticulata Blanco) and tangors (Citrus sinensis L. Osbeck $\times$ Citrus reticulata Blanco) in Brazil. Since being first reported in São Paulo, Brazil, in 2003, the disease has been intensively controlled using quinone outside inhibitor (QoI) fungicides. Isolates resistant to QoI fungicides have been detected in Florida (Vega et al. 2012). In 2017, growers reported failures in the control of Alternaria brown spot with QoI fungicides in several citrus-growing areas of São Paulo state.

Twenty-eight diseased fruit from three municipalities of São Paulo state were collected to verify the presence of isolates resistant to QoI fungicides and the possible mutations responsible for the loss of the fungus sensitivity to these fungicides. Twenty-eight monosporic isolates of A. alternata were obtained from fruit samples. Four monosporic isolates of A. alternata obtained from tangerines not treated with QoI fungicides in São Paulo state, collected in 2003 and 2004, were used to determine the baseline sensitivity to the QoI fungicides azoxystrobin and pyraclostrobin. A. alternata conidia from 7- to 9-day-old cultures grown in V8 medium were collected for the preparation of conidial suspensions $\left(10^{4}\right.$ spores $\left./ \mathrm{ml}\right)$. Conidia germination tests were performed on $1.5 \%$ agar medium containing the fungicides azoxystrobin (Vantigo, $500 \mathrm{~g}$ of active ingredient [a.i.]/kg) or pyraclostrobin (Comet, $250 \mathrm{~g}$ of a.i./liter) at $0,0.001,0.01,0.1,1,10$, and $100 \mu \mathrm{g} / \mathrm{ml}$. Because salicylhydroxamic acid (SHAM) had no effect on the sensitivity of $A$. alternata conidial germination to QoI fungicides (Mondal et al. 2005), $100 \mu \mathrm{g}$ of SHAM/ml was added to all concentrations to suppress the alternative oxidase pathway (Ma et al. 2003). Three aliquots of $30 \mu \mathrm{l}$ of conidial suspension were placed in a Petri dish and incubated at $27^{\circ} \mathrm{C}$ for $12 \mathrm{~h}$ in the dark. After the incubation period, a 50- $\mu \mathrm{l}$ aliquot of lactoglycerol was added over the conidial suspension to stop conidia germination. Spores were considered germinated when they had a germ tube greater than or equal to the conidium length. Three replicates were used for each isolate at each fungicide concentration, and 100 conidia were assessed by replication. The experiments were performed twice. The percentage of germination on each fungicide concentration were used to estimate the effective concentration to inhibit $50 \%$ of conidia germination $\left(\mathrm{EC}_{50}\right)$ by linear regression. DNA extraction, polymerase chain reaction

${ }^{\dagger}$ Corresponding author: G. M. Chitolina; E-mail: gabriel.chitolina@usp.br

The author(s) declare no conflict of interest.

(C) 2019 The American Phytopathological Society
(PCR), and sequencing were performed on two isolates collected in 2003 and two collected in 2017 to verify the presence of possible mutations that may cause loss of sensitivity to QoI fungicides. Primers cytb2f and cytb3r were used to amplify the cytochrome $b$ (cyt b) "hot spot" region containing codons 129, 137, and 143 that are responsible for loss in sensitivity to QoI fungicides (Grasso et al. 2006).

The $\mathrm{EC}_{50}$ values for baseline sensitivity of $A$. alternata collected in 2003 and 2004 ranged from 0.0009 to $0.0270 \mu \mathrm{g} / \mathrm{ml}$ for pyraclostrobin and from 0.0160 to $0.1300 \mu \mathrm{g} / \mathrm{ml}$ for azoxystrobin. These results are similar to those observed in Florida, where baseline sensitivity to pyraclostrobin and azoxystrobin ranged, respectively, from 0.004 to $0.036 \mu \mathrm{g} / \mathrm{ml}$ and from 0.060 to $0.254 \mu \mathrm{g} / \mathrm{ml}$ (Vega et al. 2012; Vega and Dewdney 2014). The isolates collected in São Paulo from the 2017 season had $\mathrm{EC}_{50}$ values ranging from 1.45 to over $100 \mu \mathrm{g} / \mathrm{ml}$ for pyraclostrobin, and all isolates had values over $100 \mu \mathrm{g} / \mathrm{ml}$ for azoxystrobin. These isolates were considered resistant to both fungicides based on the criteria adopted by Vega and Dewdney (2014), which classified as resistant the isolates with $\mathrm{EC}_{50}$ values higher than $0.5 \mu \mathrm{g} / \mathrm{ml}$ for pyraclostrobin and $5 \mu \mathrm{g} / \mathrm{ml}$ for azoxystrobin. Sequencing of the purified PCR products of the two selected resistant isolates with $\mathrm{EC}_{50}$ over $100 \mu \mathrm{g} / \mathrm{ml}$ showed the point mutation G143A, whereas the sensitive isolates showed no mutation when compared with the sensitive reference isolate CPIORI-2S (accession number JQ437357) (Vega et al. 2012). This is the first report of QoI resistance in A. alternata causing Alternaria brown spot associated with a G143A point mutation in Brazil. Further monitoring is required to ascertain the geographic extent for antiresistance measures to be taken.

\section{Literature Cited}

Grasso, V., Palermo, S., Sierotzki, H., Garibaldi, A., and Gisi, U. 2006. Cytochrome $b$ gene structure and consequences for resistance to Qo inhibitor fungicides in plant pathogens. Pest Manag. Sci. 62:465-472.

Ma, Z., Felts, D., and Michailides, T. J. 2003. Resistance to azoxystrobin in Alternaria isolates from pistachio in California. Pestic. Biochem. Physiol. 77:66-74.

Mondal, S. N., Bhatia, A., Shilts, T., and Timmer, L. W. 2005. Baseline sensitivities of fungal pathogens of fruit and foliage of citrus to azoxystrobin, pyraclostrobin, and fenbuconazole. Plant Dis. 89:1186-1194.

Vega, B., and Dewdney, M. M. 2014. Distribution of QoI resistance in populations of tangerine-infecting Alternaria alternata in Florida. Plant Dis. 98:67-76.

Vega, B., Liberti, D., Harmon, P. F., and Dewdney, M. M. 2012. A rapid resazurinbased microtiter assay to evaluate QoI sensitivity for Alternaria alternata isolates and their molecular characterization. Plant Dis. 96:1262-1270. 